\title{
Discussion on Multimedia Teaching in Colleges and Universities
}

\author{
Chen $\mathrm{Li}$ \\ Shanghai University of Engineering Science \\ Shanghai, China \\ chenli@sues.edu.cn
}

\author{
Huang Xinxiang \\ Shanghai University of Engineering Science \\ Shanghai, China \\ paulhxx@126.com
}

\begin{abstract}
With the development of society and the advancement of technology, multimedia is more and more widely used in the university education. It has changed the traditional teaching mode. However, multimedia is not everything, a detailed analysis and discussion of the advantages and disadvantages of the use of multimedia in college teaching is given. Some suggestions on the use of multimedia in the classroom teaching are offered.
\end{abstract}

Keywords-multimedia teaching; advantages; disadvantages; suggestions

\section{THE ADVANTAGES OF THE USE OF MULTIMEDIA IN COLLEGE TEACHING}

IN recent years multimedia teaching in colleges and universities has flourished. It has increasingly become the main force in the university teaching. As a teaching method, multimedia teaching has incomparable advantages compared to traditional blackboard teaching.

\section{A. The multimedia teaching is a means to achieve the modernization of education}

With the climax of the information revolution of the 21st century and the growing development of the "information superhighway", multimedia technology, as one of the important core technology for building the information superhighway, has become more and more popular[1]. Multimedia technology is not only capable of handling numeric, text, but also capable of handling graphics, images, sound and three-dimensional animation. The multimedia teaching is a means to achieve the modernization of education. Multimedia technology is more and more widely used in the college teaching.

B. Multimedia teaching is in line with the psychological characteristics of college students Units

Psychology studies on memory theory have shown that when learners acquire knowledge, they will be affected by the experience they previously have. The Experience here not only means the knowledge structure, but also means the psychological characteristics. College students have good psychological quality. They have good powers of observation and they also have strong analytical and logical ability. Moreover, they have rich perceptual experience. These are favorable factors for multimedia Teaching.

\section{Multimedia teaching makes teaching content more vivid}

Firstly, in traditional teaching, knowledge presentation is often manifested by the writing with linear structure on the blackboard. This presentation makes learners feel boring and tedious. Secondly, the content of university disciplinary is very abstract, so simple explanation sometimes does not make students fully understand. Especially it is strenuous to describe the dynamic process. However if multimedia is used, the effect will be different. In addition to text, Multimedia can insert sound, images and animation. Rich expressive power can stimulate students' interest in learning knowledge. Multimedia makes teaching more vivid[2].

D. Multimedia teaching can improve the efficiency of classroom teaching

Courseware using in multimedia teaching is often preproduced. It saves more time than writing on the spot. It has been proved that the application of multimedia courseware, to some extent, is able to save time and improve teaching efficiency.

\section{THE DISADVANTAGES OF MULTIMEDIA FOR EDUCATION}

In recent years, more and more university teachers are likely to use multimedia for education. Soon using multimedia for education becomes a fashion. In some colleges and universities, whether to use multimedia is as a primary factor to measure the quality of teaching. Are the advantages of multimedia teaching sufficient to make the traditional blackboard teaching exit from the stage of history? The answer of course is no. There are also many deficiencies in multimedia teaching.

\section{A. The excessive visualization of multimedia teaching} impedes the development of students' thinking ability.

In multimedia teaching some abstract things can be visualized by means of images, animation and sound. It help student understand text easily. But the excessive visualization of multimedia teaching will impede the development of students' thinking ability and will be unable to stimulate the imagination of students[3]. For example: when we are reading a poem, different imaginations will arise. If multimedia is used to visualize the poem, what everyone can see is an established picture. Those wonderful imaginations no longer exist. 
B. The fast-paced and informative characteristics of multimedia make students difficult to acquire knowledge. Maintaining the Integrity of the Specifications.

Courseware using in multimedia teaching is often preproduced. Teachers no longer need writing formula or law on the spot writing. It really saves a lot of time. But it is bound to greatly accelerate the teaching rhythm and at the same time it increases the amounts of information. The excessive amounts of information will make the students feel hard to breathe, let alone have time to digest the knowledge. The fast-paced and high-capacity multimedia teaching often makes students have no time to think.

\section{The standard procedure of multimedia teaching limits} the teachers' initiative.

The standard procedure of multimedia teaching is one of the biggest limitations on the applications of multimedia. When multimedia courseware is designed and used, the whole teaching process is just in a certain sequence which is pre-designed and fixed. However we know there must be a lot of uncertainties in the classroom which require teacher's wit to deal with, such as controlling the rhythm and paying attention to the response from the students, etc. The standard procedure of multimedia teaching makes teachers' initiative difficult to achieve[4].

D. Multimedia teaching easily leads to the lack of communication and interaction between teachers and students.

When the courseware of multimedia is used in teaching, the object students pay attention to will no longer be a teacher but the screen. In multimedia teaching teachers focus on not only students but also multimedia operation. The traditional "people (teacher) - people (students)" mode turns into the "people (teacher) - machine (multimedia) - people (students)" mode due to the intervention of multimedia teaching[5]. It objectively brings difficulties to the communication between the teachers and their students. If teachers do not play a leading role but only focus on multimedia operation, the lesson will become pure multimedia playback and it will be difficult to achieve good communication.

\section{SOME SUGGESTIONS ON MULTIMEDIA TEACHING}

\section{A. Emphasis should be put on the harmony and unity of content and form.}

The designation of multimedia including such items as the representation of the points of the knowledge and the arrangement of the logical sequence of the text should be carried out under the guidance of the theory of pedagogy and psychology. It should comply with the law of students' cognitive and aesthetic characteristics. The layout must follow the easy things first order and it should be paid attention to the aspects of the convergence. The colors on the layout must be simple and generous. A line of words is best no more than 20 words to avoid full screen text that will bring student repressed mood. Finally, in order to be better for the students to learn knowledge, it should be paid attention to the rational combination including the text, the sound, the image and the animation.

\section{B. Multimedia should be used according to the actual needs.}

We should make appropriate use of multimedia. People always want to get the maximum harvest with minimal effort. The selection of the media also follows that principle. We have no need to use multimedia for education if we can achieve the same effects without it. In fact, not every lesson needs multimedia presentation. Sometimes no use of multimedia makes teaching easy and can also achieve a multiplier effect.

\section{Teachers should play a leading role and form a good interaction with students in multimedia teaching.}

How do teachers play dominant and initiative role in multimedia teaching?

Firstly, teachers should control the rhythm in multimedia teaching on the reaction of the students. If teachers find most of the students "frown", it means they should slow down the multimedia rhythm and should give students sufficient time to think and digest the knowledge. If teachers find students exhibit "disagree" look, it means they should accelerate multimedia playback. In short, teachers should control the rhythm in accordance with the actual situation of the students.

Secondly, teachers should pay attention to communication and exchange with students. In order to mobilize the enthusiasm and initiative of students they can organize students to participate in the discussion.

[1] M.Zhao and L.Feng, "The Principle of the Multimedia Teaching," Journal of Xi'an University of Arts and Science, vol. 11, pp. 120-123, April 2008.

[2] Z.Y.YU, "Several Suggestions on Making Multimedia Courseware," Journal of Inner Mongolia Normal University, vol. 21, pp. 145-147, 2010

[3] H.M.Meng and L.F.Wang, "Strategies on Improving the Effectiveness of Multi-media Classroom Teaching," Journal of Shanghai Normal University, vol. 17, pp. 116-118, 2009

[4] B.Liu, "The Use of Multimedia in Teaching," Moden Reading, vol. 21, pp. 255-257, 2012

[5] L.N.Zhang, "Research on Multimedia Teaching Ability of Teachers in Colleges and Universities," Journal of Shaanxi Normal University, vol.9, pp. 108-111,2011 